understind that this may be so; otherwise he would surely be able to see that the very statistics which he gives regarding the number of dogs utilised in this country for medical research furnish the strongest of arguments against his Bill. Does he think that men who are engaged in these researches prefer to employ $\operatorname{dog} s$, and insist on using them, rather than cats or rabbits or guineapigs-for which Sir Frederick evidently has but little sympathy - for no other reason than the sheer desire to vivisect them rather than other animals which are far cheaper and more easily obtained? Is he not able to understand that dogs are never employed and are never likely to be employed for experiments unless there is some special necessity for using these animals rather than others? At any rate he may accept my assurance that it is so. And it follows that the greater number of dogs he can show to have been used the stronger is the argument for the necessity of using them. Not that his statistics are of much account, for in attempting to strengthen his case for dogs, he mixes cats up with them-unless the report of his speech is in this respect inaccurate.

But Sir Frederick Banbury's inability to assess evidence is sufficiently manifested by his argument that because the Royal Commission did not specifically state in its report that it is necessary for dogs to be employed it found no evidence sufficiently strong to authorise it to make such a statement. We know, as a matter of fact, that the Commission did discuss the question whether the exclusion of dogs might be recommended and definitely concluded against the adoption of this course. Is it, perhaps, possible that Sir Frederick Banbury-who puts himself forward as a judge in this matter-has not himself read the evidence which was presented to the Commission on the subject? This is the only hypothesis that I can suggest to render his position intelligible. But this hypothesis cannot be applied to Col. Lockwood, who appears as Sir Frederick's chief supporter-since he was a member of the Commission. Although he does not dare to say that the evidence before the Commission proved that the use of dogs is not necessary, he alleges that it did not distinctly prove "to anyone with a fair mind" that the dog alone is necessary for those "so-called scientific experiments" (sic). And this in spite of the fact that it had been proved to demonstration before the Commission-what is, of course, well known to any person who has any medical knowledge worth speaking of - that most of what we know regarding the functions of the body could only have been elucidated with the aid of experiments on dogs.

Col. Lockwood is, however, good enough to inform us by what consideration he is guided. $\mathrm{He}$ is "not ashamed to say that he is actuated by sentiment." But there is sentiment and sentiment, and we may be permitted to inquire what kind of sentiment it is that actuates Col. Lockwood. Sentiment is feeling and Col. Lockwood's feeling is for the lower animals in general, for dogs in particular, and probably-if it were to be still further analysed-most particularly for the special dog which, as he tells us, he leads about London on a string. His sentiment does not extend to humanity. He has no feeling for his own species. He prefers that mankind shall continue to be ignorant, and shall continue to suffer as a result of that ignorance, rather than that his feeling for dogs, most of which do not in any way suffer, shall be harrowed.

Sentiment of this sort has no true ring: it is false sentiment; and any man-let alone a legislator-should be ashamed to confess that he is actuated by it.

Further, Col. Lockwood is good enough " not to wish to accuse his opponents of not being so humane as himself." But Col. Lockwood's humaneness is-like his sentiment-false : it leaves humanity out of consideration. He may take it from me that his opponents repudiate this kind of humaneness and thank him neither for the comparison nor for his eulogium of their profession. Of what value is eulogium coming from such a quarter? If he and his I $2 \mathrm{I}$ fellow-members accept the services of medical men, are they not benefiting by the very experiments they denounce? To be consistent they should resolutely decline to call in the aid of physician or surgeon and betake themselves to the Christian Scientist or to any other quack they may fancy. But it is as hopeless to look for consistency from anti-vivisectionists as to expect to gather figs from thistles. As for the voters who send such persons to Parliament, one may well apply to them Carlyle's estimate of most of his fellow-citizens. But perhaps they are, on the whole, not inappropriately represented there. $\quad$ E. A. SсHÄFER.

THE TREVOR LAWRENCE ORCHID COLLECTION AT THE ROYAL GARDENS, KEW.

W HEN the late Sir J. J. Trevor Lawrence, Bart., died, an announcement was made that his well-known orchid collection at Burford had been bequeathed to Lady Lawrence with an expression of his wish that such of the plants as were especially of botanical interest should be presented to the Royal Botanic Gardens, Kew. This gift has now been made to the national orchid collection there, which has received from Lady Lawrence a large selection consisting of 580 plants, belonging to 89 genera, and representing 3.50 species mainly, but by no means exclusively, of botanical interest.

The character of the collection brought together by Sir Trevor at Burford during many years was a matter of general knowledge. It was singularly rich in rare and interesting species, owing to the fact that Sir Trevor at all times paid especial attention to whatever in the natural family was striking or unusual from a morphological point of view, apart entirely from any decorative value which it might possess. The result of this was that the Burford collection was not only thoroughly representative of the usual showy species and hybrids and on this account to be

$$
\text { NO. 2323, VOL. 93] }
$$


reckoned with in the horticultural world, but also possessed examples of most of the cultivated genera, some of which are seldom met with, and, on this account, was perhaps as important from the scientific as from the gardening point of view. It included plants from almost every quarter of the globe demanding the most diverse cultural treatment.

The magnificent selection from the collection at Burford now transferred to Kew is rich in such genera as Bulbophyllum, Cirrhopetalum, Pleurothallis, Maxillaria, Epidendrum, Eria, Angræcum, Dendrobium, and Coelogyne, and includes many species and a few genera not previously represented at Kew, some of these being rarely seen in cultivation. The genera not previously present in the Kew collection include Trichoceros, a high Andine genus very difficult to bring home alive and very difficult to cultivate afterwards, Nasonia and Quekettia, two small American genera, and Stereochilus and Sigmatogyne from Northern India. The collection also includes a number of undetermined species which have not yet flowered; in a few cases the genus to which these belong is still doubtful. These unknown plants have been derived from various sources; some of them are plants contributed to the Burford collection by Sir Trevor's son, Captain C. T. Lawrence, by whom they were obtained in West Africa.

\section{PROF. EDUARD SUESS, FOR.MEM.R.S.}

BY the death of Eduard Suess on April 26, B Austria loses her most eminent man of science, and the world one of its greatest naturalists. The son of a German merchant, domiciled in this country, Suess was born in London on August 20, 1831. The family removed, while he was still young, first to Prague and then to Vienna-but to the end of his life Suess retained his affection for what he used to call his "native land," and maintained the most cordial relations with his numerous English friends. His university career was commenced at Prague, but completed in Vienna, and at the age of twenty-one he became an assistant in the geological department of the famous Natural History Museum of the latter city. Here he worked for five years on the collections, and, as the result of his studies, published a number of important papers on graptolites, brachiopods, and other fossil forms.

It was in 1857 , however, that Suess entered upon what was his life's great work-that of a teacher. After serving ten years as an extraordinary professor in the University of Vienna, he was in 1867 appointed to the full professorship of geology, a post which he held for thirtyfour years, retiring as emeritus professor in I90I. Of his success as a teacher it is needless to speak, for he numbered among his pupils Neumayr, Mojsisovics, Fuchs, Waagen, Penck, and other distinguished geologists, many of whom caught from their master that grasp of detail, combined with powers of generalisation, that so eminently distinguished him. The writer of this notice recalls with pleasure the happy time he spent with Suess forty years ago, when he had the opportunity of witnessing the delightful relations that existed between the professor and his students. Not only during geological excursions in the neighbourhood of Vienna was the charm of Suess's society felt, but in the Wurstel-Prater, where we joined the young fellows during hours of relaxation-in the beer-gardens, and even on the "merry-go-rounds." Yet, amid all the fun and frolic, the signs of affectionate respect and devotion to the great teacher were never for a moment wanting.

It was at this time that Suess's daughter became engaged to his most distinguished pupil, the young Bavarian, Melchior Neumayr. After working for a time on the Geological Survey of Austria, Neumayr had established a great reputation as a palæontologist, and at the age of twentyeight became a colleague of Suess, as professor of palæontology in the Vienna University. Greatly impressed by reading the "Origin of Species," he entered into correspondence with Darwin, by whom his work was held in high estimation, and in the end he came to be regarded as the stoutest champion of evolution on the geological side.

Suess's own researches ranged over every branch of geological science, as may be seen from the titles of sixty memoirs and books published by him prior to 1875 . But in this year there appeared his remarkable work, "Die Entstehung der Alpen," to be followed five years later by the first part of the still more famous "Antlitz der Erde." In this great work, which engaged his labours during twenty-five years, Suess aimed at no less a task than taking a comprehensive survey of all that has been accomplished in elucidating the geological structure of every part of the globe, and drawing general conclusions from that survey. How admirably this herculean undertaking was performed is told-with an estimate of the great merits, the small defects, and the enormous influence exerted by this monumental work-by Sir Archibald Geikie in a contribution to the series of "Scientific Worthies" (see Nature, vol. 1xxii., May 4, 1905). It will suffice here to say that the book will undoubtedly take its place as a scientific classic, side by side with Hutton's "Theory of the Earth" and Lyell's "Principles of Geology."

In 1890 there came a sad interruption to Suess's scientific labours. His distinguished son-in-law and colleague, Neumayr, died at the early age of forty-four, when only the first volume of the great work on which he was engaged, "Die Stämme des Thierreichs," had been published. It is very touching, even at this date, to read the letters in which Suess wrote of his great sorrow to his friends; but fortunately these same letters contained the expression of a new hope, founded on the fact that his own son had just taken his doctor's degree in geology. Happily, Suess lived to see his son become an extraordinary professor in the University, to find him the author of valuable geological papers, and, shortly before No. 2323, VOI. 93] 